\title{
ANALISIS HUKUM SECARA ANALOGI PENERAPAN ASAS PEMISAHAN HORIZONTAL PADA PRAKTEK JUAL BELI TANAH TIDAK BESERTA DENGAN POHON KELAPA DI ATASNYA DI KEC. PATILANGGIO KAB. POHUWATO
}

\author{
OLEH:
}

\author{
Nasrullah \\ Dosen Fakultas Hukum \\ Universitas Ichsan Gorontalo \\ email: nasrullahnurdin130@gmail.com
}

\begin{abstract}
The principle of horizontal separation in the LoA is a principle that separates the ownership of the land by the right to the property on the ground or attached to the land, where the existence of the object attached to the land there is a time limit provision either by agreement or on the basis of the provisions of the legislation.Based on the analogy of law in the above analogy, it can be concluded that the practice of buying and selling land is not accompanied by coconut trees on it also apply the principle of horizontal separation due to the separation or difference of legal subject holder of property rights to the land with legal subject holder of property rights on coconut trees. But if you look at the various legal bases in the BAL which regulate the principles of horizontal separation such as Right of Use, Right of Use, Right to Use, Lease of Land for Building Establishment, Right of Ride, and Lease of Land for Agriculture all have clear clear time limits on the basis of agreement and also on the basis of the provisions of legislation. And for the duration of the term is not over so long also the holder of property rights on the land should not use his right either to build the building, manage or make it as collateral (collateral) debts and so on. While in the sale and purchase of separate land with coconut trees on it is not so, because there is no provision of clear time limit of the existence of coconut trees on the land rights of others and holders of land rights are still entitled to grow crops on their property rights. So the basic difference is what distinguishes the application of the principle of horizontal separation in BAL with the principle of separation of horisoltan on the practice of buying and selling land is not accompanied by coconut trees on it.
\end{abstract}

Keyword : Agreement, Land, Principles of Horizontal Separation

\section{A. Pendahuluan}

Manusia dan tanah memiliki hubungan yang abadi, sejak lahir hingga meninggal dunia hubungan manusia dengan tanah tetap ada. Tanah dan manusia tidak bisa dipisahkan, karena tanah memiliki fungsi ekonomis yang diatasnya dibangun ruang sosial, berbagai hubungan dijalin dalam kehidupan bermasyarakat.

Seiring dengan bertambahnya jumlah manusia, semakin besar pula kebutuhan manusia akan tanah baik di sektor pertanian maupun di sektor pembangunan. Namun keberadaan tanah yang semaki terbatas, tidak sebanding dengan pertambahan jumlah penduduk yang senantiasa bertambah. Sehingga tanah tidak jarang menjadi objek persengketaan, dan dilakukan segalah upaya untuk mempertahankan hak atas tanah 
tersebut, baik melalui proses litigasi, non-litigasi bahkan sampai terjadi pembunuhan untuk mempertahankan hak milik atas tanah.

Keberadaan Undang-Undang Pokok Agraria (UUPA) sangatlah penting untuk memberikan kepastian hukum di bidang pertanahaan. Karena sebelum berlakunya Undang-Undang Pokok Agararia terdapat dualismen yang mengatur masalah pertanahan, yaitu hukum pertanahan yang berdasarkan pada hukum adat dan hukum pertanahan yang berdasarkan pada KUH Perdata.

Hukum adat yang dijadikan dasar karena hukum tersebut dianut oleh sebagian besar bangsa rakyat Indonesia, sehingga hukum adat tentang tanah mempuyai kedudukan istimewa dalam pembentukan hukum agrarian nasional (Urip Santoso, 2012:67).

UUPA berasaskan hukum adat, namun demikian berbeda dengan ketentuan hukum adat yang tidak mengenal hak kebendaan, UUPA mengandung sifat kebendaan, hal mana terlihat dari keharusan adanya pendaftaran hak atas tanah yang mengandung aspek publisitas dan mengandung aspek spesialitas, dua aspek yang selalu merupakan ciri hak kebendaan (Mariam Darus Badrulzaman, 1983:64).

Hukum adat menganut asas pemisahan horisontal. Sejalan dengan hukum adat ini, maka UUPA juga mengenal asas pemisahan horisontal (Mariam Darus Badrulzaman, 1983:16). Hal ini diatur dalam Pasal 5 UUPA, yang menyatakan bahwa Hukum agraria Indonesia adalah hukum adat, dan kalimat itu tersirat dalam UUPA juga berlaku asas-asas yang terkandung dalam hukum adat terutama yang berkaitan dengan tanah.

Dalam prakteknya, salah satu bentuk penerapan asas pemisahan horisontal adalah jual beli pohon kelapa tidak beserta dengan tanahnya atau membeli tanahnya tidak beserta dengan kelapanya. Dimana jual belia ini dilakukan hanya dengan selembar kwitansi, meskipun hal ini tidak dilarang namun nantinya tidak menutup kemungkinan dalam proses pembuat sertifikat hak milik akan mengalami kesulitan. 
Mengenai penerapan asas pemisahan horisontal melalui praktek jual beli tanah tidak beserta dengan pohon kelapa di atasnya tidak diatur dalam UUPA. Penerapan asas pemisahan horisontal yang diatur dalam UUPA agrarian adalah sewa tanah, Hak Guna Bangunan, Hak Guna Usaha dan Hak Pakai. Ini artinya bahwa, sebenarnya ada kekosongan hukum mengenai praktek jual beli pohon kepala tidak beserta dengan tanahnya atau menjual tanahnya tidak beserta dengan pohon kelapanya. Praktek jual beli seperti di atas sudah menjadi suatu kebiasaan masyarakat di Kecamatan Patilanggio yang tidak diketahui kapan awal mulanya praktek jual beli terebut. Dan selain itu banyak kasus pertanahan yang lahir dari penerapan praktik jual beli pohon kelapa tidak beserta dengan tanahnya, misalnya dalam satu hektar lahan yang diatasnya terdapat pohon kelapa yang pemiliknya lebih dari 1 orang di atas lahan 1 hektar tanah. Sehingga ketikan ingin membangun di atas tanah hak milik harus membayar kepada semua pemilik pohon kelapa tersebut dan tidak adanya pembagian yang jelas pada pemilik kelapa tersebut. Oleh karena itu, permasalahan yang hendak diuraikan dalam tulisan ini yaitu Bagaimanakah penganturan asas pemisahan horisontal dalam UUPA? dan Apakah praktek jual beli tanah tidak berserta dengan pohon kelapa di atasnya di Kec. Patilanggio jika dianalisis secara analogi sama dengan asas pemisahan horisontal yang dianut dalam UUPA?

\section{B. Metode Penelitian}

Tipe penelitian yang akan digunakan dalam penelitian ini adalah tipe penelitian normatif empiris. Dimana teknik-teknik yang ada dalam kedua tipe penelitian ini akan penulis gunakan untuk menganalisis masalah yang akan penulis pecahkan dalam menjawab rumusan masalah.

Yang menjadi objek dalam penelitian ini adalah penerapan asas pemisahan horisontal dalam praktik jual beli tanah tidak beserta dengan pohon kelapa di atasnya. Sehingganya penelitian ini memerlukan data primer dan data sekunder. Untuk memperoleh data primer maka penulis akan melakukan wawancara dengan pihak Kantor Badan Pertanahan Nasional, pihak PPAT, Camat Patilanggio Kab. Pohuwato. Di mana data primer ini diperoleh dengan cara melakukan Intervieu (wawancara) langsung dengan para 
pihak yang dianggap kompeten dan memiliki pengalaman terkait masalah yang ada dalam penelitian ini. Sedangkan untuk Data sekunder yang akan digunakan dalam penelitian ini diperoleh dengan cara melakukan pengumpulan bahan hukum primer dalam peraturan perundang-undangan, bahan hukum sekunder baik buku, jurna dan lain-lain.

\section{Hasil Penelitian Dan Pembahasan}

\section{Pengaturan Asas Pemisahan Horisontal Dalam UUPA}

Asas pemisahan horizontal adalah asas dalam hukum pertanahan yang diatur dalam hukum adat. Berdasarkan asas pemisahan horisoltal maka tanah terlepas dari segala benda yang melekat padanya.

Dalam hukum adat tanah merupakan benda yang sangat istimewa, sehingga pengaturan mengenai tanah dalam hukum adat, mempunyai lingkup tersendiri yang terpisah dan benda lain yang bukan tanah. Kedudukan istimewa tersebut adalah sedemikian rupa sehingga dalam hukum adat pengaturan hukum tanah, transaksi tanah dan transaksi yang berhubungan dengan tanah diatur tersendiri. Yang dimaksud dengan transaksi yang berhubungan dengan tanah dalam hukum adat adalah transaksi atas tanah yang tidak langsung, misalnya transaksi bagi hasil, sewa tanah, jaminan atas tanah yang ada di jawa dikenal dengan istilah tanggungan atau jonggolan, dan sebagainya. Dalam hukum adat bangunan dan tanaman diatur terpisah dan berada dalam lingkup benda bukan tanah dan hukum tentang perbuatan jasa. Dengan demikian berdasarkan asas pemisahan horizontal dalam hukum adat dikenal pembedaan antara benda tanah dan benda bukan tanah.

UUPA menganut asas hukum adat karena itu juga menganut asas pemisahan horizontal hal mana tersirat dalam ketentuan Pasal 5 UUPA.

"hukum agrarian yang berlaku atas bumi, air, dan ruang angkasa ialah hukum adat, sepanjang tidak bertentangan dengan kepentingan nasional dan negara, yang berdasarkan atas persatuan bangsa..."

Dengan demikian UUPA juga menganut asas pemisahan horizontal. Hal mana juga terlihat bahwa dalam UUPA dan peraturan pelaksanaanya tidak mengkaitkan tanah dengan 
benda lain yang melekat pada tanah. Dalam UUPA tidak terdapat ketentuan yang mengatur status bangunan atau rumah ataupun tanaman, karena UUPA menganut asas pemisahan horisontal.

Mengenai penerapan asas pemisahan horisontal pada praktek jual beli tanah tidak beserta dengan pohon kelapa di atasnya tidak diatur oleh UUPA. Asas pemisahan horisontal yang diatur dalam UUPA hanyalah persoalah, yaitu:

a. Hak Guna Usaha (HGU) yang disebutkan dalam Pasal 16 ayat (1) huruf b UUPA, secara khusus diatur dalam Pasal 28 sampai dengan Pasal 34 UUPA;

b. Hak Guna Bangunan (HGB) yang disebutkan dalam Pasal 16 ayat (1) huruf c UUPA. Secara khusus diatur dalam Pasal 35 sampai dengan Pasal 40 UUPA;

c. Hak Pakai (HP) disebutkan dalam Pasal 16 ayat 1 huruf d UUPA. Secara khusus diatur dalam Pasal 41 sampai dengan Pasal 43 UUPA;

d. Hak Sewa Untuk Bangunan (HSUB) yang disebutkan dalam Pasal 16 ayat (1) huruf e UUPA. Secara khusus diatur dalam Pasal 44 dan Pasal 45 UUPA; dan

e. Selai itu ada hak atas tanah yang bersifat sementara yang juga menerapkan asas pemisahan horisontal yaitu:

1. Hak Menumpang. Hak Menumpang yang dimaksud di sini bukan menumpang pada rumah atau bangunan, tetapi Hak Menumpang yang dimaksud di sini adalah Hak Menumpang di atas tanah milik orang lain, yang menurut Boedi Harsono menumpang untuk mendirikan dan menempati rumah di atas tanah pekarangan milik orang lain.

2. Hak Sewa Tanah Pertanian. UUPA agraria sendiri tidak memberikan definisi tentang apa yang dimaksdu dengan Hak Sewa Tanah Pertanian. Yang dimaksdu dengan Hak Sewa Tanah Pertanian adalah suatu perbuatan hukum dalam bentuk penyerahan penguasaan tanah pertanian oleh pemilik tanah kepada pihak lain (penyewa) dalam jangka waktu tertentu dan sejumlah uang sebagai sewa yang ditetapkan atas dasar kesepakatan kedua belah pihak.

Jika menganalisis berbagai ketentuan hukum di atas yang mengatur mengenai pemisahan horisontal, maka dapat disimpulkan bahwa asas pemisahan horisontal dalam 
UUPA merupakan asas yang memisahan hak milik atas tanah dengan hak milik atas benda yang ada di atas tanah atau melekat pada tanah tersebut, di mana keberadaan benda yang melekat pada tanah tersebut ada ketentuan batasan waktunya baik berdasarkan kesepakatan maupun atas dasar ketentuan peraturan perundang-undangan. Jadi tidak hanya mengatur pemisahan hak milik atas tanah dengan hak milik atas benda yang ada di atasnya, tetapi juga mengatur tentang batasan waktu hak milik atas benda yang melekat atas tanah tersebut, baik atas dasar kesepakatan maupun atas dasar ketentuan peraturan perundang-undangan

2. Praktek jual beli tanah tidak berserta dengan pohon kelapa di atasnya di Kec. Patilanggio jika dianalisis secara analogi dengan asas pemisahan horisoltal yang dianut dalam UUPA

Salah satu pasal dalam UUPA yang mengatur masalah asas pemisahan horizontal dapat ditemukan dalamPasal 44 ayat (1) UUPA, yaitu:

Seorang atau suatu badan hukum mempunyai hak sewa atas tanah, apabila ia berhak menggunakan tanah hak milik orang lain untuk keperluan bangunan, dengan membayar kepada pemiliknya, sejumlah uang sebagai uang sewa

Implementasi dari asas pemisahan horizontal adalah Hak Sewa Untuk Bangunan, yaitu seseorang atau badan hukum menyewa tanah Hak Milik orang lain yang kosong atau tidak ada bangunanya dengan membayar sejumlah uang sebagai uang sewa yang besarnya ditetapkan atas dasar kesepakatan, untuk jangka waktu tertentu, dan penyewa diberi hak mendirikan bangunan yan digunakan untuk jangka waktu tertentu yang disepakati kedua belah pihak.

Dalam Hak Sewa Untuk Bangunan ada pemisahan secara horizontal antara pemilik tanah dengan pemilik bangunan yang ada diatasnya, yaitu tanahnya milik pemilik tanah, sedangkan bangunanya milik penyewa tanah, namun berdirinya bangunan tersebut di atas tanah Hak Milik orang lain atas dasar Hak Sewa Untuk Bangunan.

Ketentuan-ketentuan yang dimuat dalam Undang-Undang Pokok Agraria (UUPA) hanyalah asas-asas dan soal-soal agraria dalam garis besarnya saja, dan oleh karena itu disebut Undang-Undang Pokok Agraria. Pengertian pokok dalam UUPA menunjukkan 
bahwa substansi yang diatur dalam UUPA hanyalah ketentuan-ketentuan pokoknya. Jadi, kata "pokok" dalam UUPA bukan menunjukkan pada jenis peraturan perundang-undangan. Maksud pembentukan UUPA menempatkan UUPA sebagai peraturan inti yang hanya berfungsi mengatur hal-hal pokok tentang agraria. UUPA sebagai undang-undang induk yang harus dijadikan acuan bagi undang-undang lain yang beraitan dengan agraria. UUPA juga sebagai undang-undang yang meletakkan dasar-dasar bagi pembentukan undangundang lain yang berkaitan dengan agraria. UUPA masih membutukan peraturan perlaksanaan baik yang berbentuk undang-undang, peraturan pemerintah, keputusan Presiden, maupun peraturan daerah. Peraturan tersebut bersifat melaksanakan, menjabarkan, dan melengkapi kehendak pasal-pasal dalam UUPA (Muchsin dan Imam Koeswahyono, 2008:6).

Persyaratan mengenai objek jual beli tanah adalah bahwa penjual tanah benarbenar pemilik tanah yang bisa dibuktikan dengan sertifikat tanah atau alat bukti penguasaan tanah yang sah dan tanah yang akan dijual harus jelas statusnya baik dari segi data yuridis maupun data fisik, begitu pula status tanah tersebut tidak boleh dalam keadaan sengketa atau dijadikan agunan dengan hak tanggungan atau dalam status tergadai.

Selainproses peralihan hak milik dengan jual beli yang dilakukan secara formal, peralihan hak dengan jual beli juga dapat dilakukan dengan cara adat atau lebih dikenal dengan jual beli di bawah tangan yang biasa dilakukan di depan kepala desa oleh pihakpihak yang berkepentingan yang dilakukan di depan saksi, keluarga, kerabat, dan tetangga dan biasanya hanya dibuktikan dengan selembar kwitansi pembayaran.

Jual beli tanah tidak beserta dengan pohon kelapa di atasnya di Kec. Patilanggio tidaklah bersumber dari hukum adat, tetapi bersumber dari kebiasaan-kebiasaan masyarakat yang tidak diketahui kapan awal mulanya kebiasaan tersebut.

Namun berdasarkan wawancara dengan warga Kec. Patilanggio yang intinya bahwa alasan masyarakat pada zaman dahulu menjual kelapa tidak beserta dengan tanahnya bermacam-macam, ada yang beralasan karena masih membutuhkan tanahnya, dan juga beralasan karena nilai jual pohon kelapa jauh lebih tinggi dibandingkan dengan nilai jual 
tanahnya, sehingganya hanya menjual pohon kelapanya saja. Bahkan adapulah yang sebaliknya menjual tanahnya tetapi tidak menjual pohon kelapanya dengan alasan yang sama, yaitu nilai jual pohon kelapa jauh lebih tinggi dibandikan dengan nilai jual tanahnya dan selain itu penjual masih mengharapkan hasil dari pohon kelapa tersebut sehingganya hanya menjual tanahnya saja.

Peraktek jual beli tanah yang dilakukan dengan jual beli di bawah tangan umumnya dilakukan oleh masyarakat di Kec. Patilanggio, disebabkan oleh karena rendahnya pemahaman mengenai jual beli tanah dan rendahnya kesadaran masyarakat mengenai pentingnya peralihan hak milik dengan Akta Jual Beli yang dibuat oleh PPAT.

Selain itu, pada zaman dahulu sangatlah susah untuk menjangkau yang namanya PPAT, selain menempuh jarak yang cukup jauh, jalan yang harus dilalui juga cukup sulit. Dan untuk melibatkan PPAT, masyarakat harus menempu proses yang panjang dan harus menyediakan berbagai berkas. Sedangkan jika dilakukan jual beli di bawah tangan, masyarakat merasa mudah dan tidak harus menunggu terlalu lama dan biayanya pun murah.

Mengenai praktek jual beli pohon kelapa ini, menurut Boki Bahmid. SH bahwa Pejabat Pembuat Akta Tanah (PPAT) tidak bisa membuatkan akta jual beli pohon kelapa yang terpisah dengan tanahnya, alasan utamanya karena jual beli pohon kelapa bukan objek yang menjadi kewenangan PPAT untuk membuatkan akta jual beli dan selain itu draf atau konsep akta memang sudah dibakukan oleh pihak kementerian sehingga Pejabat Pembuat Akta Tanah tinggal mengisi bagian yang kosong pada draf atau konsep akta tersebut. Sehingga pihak PPAT tidak bisa membuatkan akta peralihan hak milik atas pohon kelapa. Kecuali akta peralihan Hak Milik (jual beli) tanah mengikut atau tidak beserta dengan bangunan dan/atau tanaman yang melekat di atas tanah tersebut. Meskipun memang benar terjadi pemisahan secara horisontal antara pemilikan atas tanah dan pemilikan atas tanaman pohon kelapa.

Selain itu, menurut bapak Taufan Adhitya, SH selaku Kepala Sub Bagian Tata Usaha Badan Pertanahan Nasional RI Kantor Pertanahan Kabupaten Pohuwato, menjelaskan bahwa pihak Badan Pertanahan sendiri tidak bisa menerima pendaftaran atas tanaman 
pohon kelapa yang terpisah dengan tanahnya, kecuali pendaftaran tanah yang mengiku atau beserta dengan tanaman dan/atau bangunan yang ada di atasnya.

Dari kasus jual beli pohon kelapa terpisah dengan tanahnya melahirkan pertanyaan yaitu, apakah sebenarnya jual beli tanah tidak beserta dengan pohon kelapa di atasnya tidak bertentanggan dengan asas pemisahan horisontal yang dianut dalam UUPA?

Karena tidak adanya dasar hukum yang mengatur masalah jual tanah tidak beserta dengan pohon kelapa di atasnya, maka kasus ini harus dianalisis secara induktif dengan menganalisi dari hal yang bersifat khusus ke hal yang bersifat umum. Sehingganya harus mencari jenis penerapan asas pemisahan horisontal yang dianut dalam UUPA. Penerapan asas pemisahan horisontal yang diatur dalam UUPA yaitu Sewa Tanah Untuk Bangunan, Hak Guna Bangunan, Hak Guna Usaha, Hak Pakai.

Salah satu cara yang bisa dilakukan untuk menganalisis suatu kasus yang tidak ada dasar hukumnya yaitu dengan cara metode induktif, yaitu berfikir dari peristiwa khusus ke peristiwa umum. Sehingganya bisa dilakukan dengan cara analogi. Oleh karena UUPA hanya menerapkan asas pemisahan horisontal pada Hak Guna Usaha, Hak Guna Bangunan, Hak Pakai, dan Sewa Tanah Untuk Bangunan, maka harus dilakukan kontruksi hukum. Oleh karena itu hari mencari esensi dari perbuatan hukum jual beli pohon kelapa tidak beserta dengan tanahnya. Dan begitu pula Hak Guna Usaha, Hak Guna Bangunan, Hak Pakai, dan Sewa Tanah Untuk Bangunan harus dicari esensinya.

> Hak Guna Usaha

Hak Guna Usaha dilakukan di atas tanah negara. Sedangkan bidang usaha yang dimaksud adalah bidan usaha di bidang pertanian, perkebunan, peternakan, dan perikanan. Jika usaha tersebut berupa usaha di bidang perkebunan kelapa, maka hak milik atas kelapa tersebut ada pada pemegang Hak Guna Usaha, sedangkan tanahnya tetap milik negara. Dengan jangka waktu paling lama lama 35 tahun, dapat diperpanjang 25 tahun dan dapat diperbaharui sampai 35 tahun.

$>$ Hak Guna Bangunan

Hak Guna Bangunan bisa didirikan di atas tanah hak milik orang lain. Sehingganya ada hak milik atas bangunan yang berdiri dengan status Hak Guna Bangunan yang 
berdiri di atas tanah hak milik orang lain. Sehingganya ada hak milik atas bangunan dengan status Hak Guna Bangunandi atas tanah hak milik orang lain. dengan jangka waktu paling lama 30 tahun.

$>$ Hak Pakai

Hak Pakai atas tanah bisa dilakukan di atas tanah Negara, di atas tanah Hak Pengelolaan, dan di atas tanah Hak Milik orang lain, baik untuk kegiatan mendirikan bangunan atau pun untuk kegiatan pertanian, perkebunan, perikanan, dan peternakan. Jikalau Hak Pakai terebut di atas tanah Hak Milik orang lain untuk mendirikan bangunan, maka bangunan tersebut Hak Milik dari pemegang Hak Pakai dan tanahnya tetap Hak Milik orang lain. Dengan jangka waktu paling lama 25 tahun.

\section{$>$ Sewa Tanah Untuk Bangunan}

Penyewah tanah mendirikan bangunan di atas tanah Hak Milik orang lain dengan perjanjian sewa tanah untuk mendirikan bangunan. Sehingganya hak penyewa tanah atas bangunan adalah hak milik atas bangunan tersebut. Tetapi berdirinya banguna tersebut di atas tanah Hak Milik orang lain dengan status hak sewa. Sehinggan tanahnya tetap Hak Milik dari penyewa tanah. Sehingganya ada hak milik atas bangun di atas tanah Hak Milik orang lain. dengan jangka waktu berdasarkan kesepakatan kedua bela pihak antara penyewa dan yang menyewa.

Jual Beli Pohon Kelapa TidakBeserta Dengan Tanahnya

Sedangkan jika dianalsis akibat hukum dari perbuatan hukum perjanjian jual beli pohon kelapa tidak beserta dengan tanahnya, maka harus dicari akibat hukum dari perjanjian jual beli pohon kelapa tidak beserta dengan tanahnya. Akibat hukum dari perjanjian jual beli adalah peralihan hak milik. Sehingganya perjanjian jual beli pohon kelapa tidak beserta dengan tanahnya juga terjadi pemisahan horisontal, yaitu pembeli pohon kelapa menguasai pohon kelapa tersebut dengan status hak milik atas pohon kelapa, sedangkan tanahnya tetap Hak Milik dari penjual pohon kelapa. Namun akibat hukum dari jual beli pohon kelapa tidak beserta dengan tanahnya terjadi peralihan hak milik tanpa adanya ketentuan yang jelas mengenai 
batasan waktu. Sehingganya berbeda dengan asas pemisahan horisontal yang dianut dalam UUPA.

Dengan hasil analisis di atas ditemukan bahwa, esensi dari Hak Guna Bangunan, Hak Pakai, dan Hak Sewa Untuk Bangunan yaitu adanya hak milik atas benda bukan tanah di atas tanah Hak Milik, sedangkan esensi Hak Guna Usaha yaitu adanya hak milik atas benda bukan tanah di atas tanah Negara. Sehinggan dari ke-4 jenis hak atas tanah di atas, semuanya menerapkan asas pemisahan horisontal dengan esensi yaitu adanya hak milik atas benda bukan tanah di atas tanah Hak Milik. Begitu pula pada praktek jual beli pohon kelapa tidak beserta dengan tanahnya, memiliki esensi adanya hak milik atas benda bukan tanah di atas tanah Hak Milik. Dengan demikian ditemukan bahwa "adanya hak milik atas benda bukan tanah di atas tanah Hak Milik" merupakan genus (peristiwa umum), sedangkan HGB, HGU, Hak Pakai, Sewa Tanah Untuk Bangunan dan Jual beli tanah tidak beserta dengan pohon kelapanya adalah species (peristiwa khusus).

Mengenai hal ini penulis memahami bahwa sebenarnya asas pemisahan horisontal ini bukan hanya dalam konteks terpisahnya pemegang hak milik atas benda bukan tanah di atas tanah hak milik orang lain. Jika pemahaman ini yang kita jadikan acuan maka kita akan membangun suatu kesimpulan bahwa jual beli tanah tidak beserta dengan pohon kelapa di atasnya juga menerapkan asas pemisahan horisontal seperti yang telah diatur dalam UUPA. Namun menurut penulis hal ini sedikit keliru. Pemahaman penulis sendiri bahwa asas pemisahan horisontal bukan hanya dalam konteks terpisahnya pemegang hak milik atas benda bukan tanah di atas tanah hak milik orang lain, tetapi pemahaman tersebut perlu diperluas atau ditambah bahwa asas pemisahan horisontal adalah asas yang menjelaskan bahwa subjek hukum pemegang hak milik atas benda di atas tanah, berbeda dengan subjek hukum pemegang hak milik atas tanah tersebut, di mana keberadaan benda di atas tanah hak milik orang lain memiliki jangka waktu yang jelas sesuai dengan ketentuan peraturan perundang-undangan atau kesepakatan. Pemahaman ini dapat dilihat berdasarkan anaolgi hukum di atas dengan tidak mengabaikan dasar hukum yang ada. 
Selain itu akibat hukum dari jual beli tanah tidak beserta dengan pohon kelapa di atasnya memiliki perbedaan dengan asas pemisahan horisontal yang dianut dalam UUPA, perbedaan tersebut yaitu:

1. Pada praktek jual beli pohon kelapa tidak beserta dengan tanahnya tidak ada ketentuan yang jelas mengenai batasan waktu, sedangkan penerapan asas pemisahan horisontal yang diatur dalam UUPA memiliki ketentuan batasan waktu yang jelas;

2. Penjual pohon kelapa masih memiliki hak untuk bercocok tanam di atas tanahnya, misalnya menanam jagung dan lain-lain.

3. Jual beli pohon kelapa tidak beserta dengan tanahnya berasal dari hukum kebiasaan.

4. Pejabat Pembuat Akta Tanah (PPAT) tidak bisa membuatkan akta jual beli pohon kelapa tidak beserta dengan tanahnya, kecuali akta jual beli tanah.

5. Pihak Badan Pertanahan sendiri tidak bisa mendaftarkan tanaman pohon kelapa terpisah dengan tanahnya. Sehingganya tidak ada sertifikat atas tanaman pohon kelapa.

Dari berbagai perbedaan di atas, penulis berpendapat bahwa praktek jual beli pohon kelapa tidak beserta dengan tanahnya tidak sama dengan asas pemisahan horisontal yang dianut dalam UUPA.

\section{Kesimpulan}

Berdasarkan hasil penelitian di atas, penulis menarik kesimpulan yaitu:

1. Asas pemisahan horisontal dalam UUPA merupakan asas yang memisahan hak milik atas tanah dengan hak milik atas benda yang ada di atas tanah atau melekat pada tanah tersebut, di mana keberadaan benda yang melekat pada tanah tersebut ada ketentuan batasan waktunya baik berdasarkan kesepakatan maupun atas dasar ketentuan peraturan perundang-undangan.

2. Berdasarkananalisis hukum secara analogi di atas, dapat disimpulkan bahwa praktek jual beli tanah tidak beserta dengan pohon kelapa di atasnya juga menerapkan asas pemisahan horisontal karena adanya pemisahan atau perbedaan subjek hukum pemegang hak milik atas tanah dengan subjek hukum pemegang hak milik atas pohon 
kelapa. Tetapi jika memperhatikan berbagai dasar hukum dalam UUPA yang mengatur tentang asas pemisahan horisontal seperti Hak Guna Usaha, Hak Guna Bangunan, Hak Pakai, Sewa Tanah Untuk Mendirikan Bangunan, Hak Menumpang, dan Sewa Tanah Untuk Pertanian semuanya memiliki ketentuan batasan waktu yang jelas baik atas dasar kesepakatan mau pun atas dasar ketentuan peraturan perundang-undangan. Dan selama jangka waktunya belum berakhir selama itu pula pemegang hak milik atas tanah tidak boleh menggunakan haknya baik untuk mendirikan bangunan, mengelolah atau menjadikannya sebagai agunan (jaminan) utang piutang dan sebagainya. Sedangkan dalam jual beli tanah terpisah dengan pohon kelapa di atasnya tidak demikian, karena tidak adanya ketentuan batasan waktu yang jelas keberadaan pohon kelapa di atas tanah hak milik orang lain dan pemegang hak milik atas tanah masih berhak untuk bercocok tanam di atas tanah hak miliknya. Sehingga perbedaan yang mendasar inilah yang membedakan penerapan asas pemisahan horisontal dalam UUPA dengan asas pemisahan horisoltan pada praktek jual beli tanah tidak beserta dengan pohon kelapa di atasnya.

\section{Daftar Pustaka}

Mariam Darus Badrulzaman, 1983. Mencari Sistem Hukum Benda Nasional, Bandung, Alumni.

Mariam Darus Badrulzaman, 1983. Perjanjian Kredit Bank, Bandung,Alumni.

Muchsin dan Imam Koeswahyono, 2008. Aspek Kebijakan Hukum Penatagunaan Tanah Dan Penataan Ruang. Jakarta, Sinar Grafika.

Urip Santoso, 20012. Hukum Agrarian Kajian Komprehensip, Jakarta, Kencana. http://hkmagraria.blogspot.co.id/2009/01/aspek-hukum-tanah-adat.html. 